\title{
A comparative study of anticonvulsant effect of phenytoin and lamotrigine in albino mice
}

Department of Pharmacology, Govt. Medical College, Banda, Uttar Pradesh, India

Received: 25 August 2017

Accepted: 21 September 2017

\section{*Correspondence to:}

Dr. Ashok Kumar Singh, Email: daksinghgmcbanda@ gmail.com

Copyright: (C) the author(s), publisher and licensee Medip Academy. This is an openaccess article distributed under the terms of the Creative Commons Attribution NonCommercial License, which permits unrestricted noncommercial use, distribution, and reproduction in any medium, provided the original work is properly cited.

\author{
Ashok Kumar Singh*
}

\begin{abstract}
Background: The anticonvulsant activity of lamotrigine has been extensively studied and its role is established. Lamotrigine have shown recently to be useful in various epileptic seizures. Since antiepileptic drugs are used for longer duration, so less toxic drugs should be chosen. So, in the present study the Lamotrigine has been chosen to compare the anticonvulsant action, effectiveness, toxicity and lethal dose of the drug used in the study keeping the phenytoin as a standard drug.
\end{abstract}

Methods: The present study has been carried out in the Department of Pharmacology, Darbhanga Medical College, Laheriasarai. Induction of seizure with the help of electro-convulsiometer in albino mice was done followed by the observation of the anti-convulsant activity of lamotrigine in comparison with phenytoin sodium was made. Side effects or toxicity of the drugs used (Acute neurotoxicity) was observed.

Results: Lamotrigine caused lower mortality in comparison to phenytoin for the same dose ranges. The anticonvulsant properties of Lamotrigine were compared with phenytoin and the effect has been found to be satisfactory. Lamotrigine protected experimentally induced grand mal seizure and was observed to be ineffective against experimentally induced petit mal seizure. The ED 50 of Lamotrigine was found to be higher and the toxic dose was also higher in comparision with standard drugs. The protective index of lamotrigine was found to be less than that of phenytoin. Margin of safety of the drug was found to be more due to their shorter protective index than that of phenytoin.

Conclusions: Lamotrigine can be used clinically as anticonvulsant in Grandmal type of epilepsy but not in Petitmal epilepsy, and has equivocal anticonvulsant effect but slightly less toxicity to phenytoin but further elaborate screening of the drug by various experiments is needed to come to a precise conclusion.

Keywords: Anticonvulsant effect, Albino mice, Phenytoin, Lamotrigine

\section{INTRODUCTION}

Epilepsy is the most common serious neurological disorder affecting an estimated 50 million people worldwide. The striking synergism between hypertension and stroke is more epileptogenic than other risk factors. ${ }^{1}$ The involvement of noradrenergic system in modulation of seizure activity is well documented. The noradrenergic system was demonstrated to participate in the occurrence of seizure in epileptic EL mice and to increase epileptiform discharge in rat limbic system via $\beta$-adrenergic receptor stimulation. $^{2}$

In experimental epileptology, to detect a substance possessing anticonvulsant activity, a huge number of compounds undergo examination in the first anticonvulsant screening test in rodents. ${ }^{3,4}$

Phenytoin and carbamazepine prolong the inactive state of the voltage-dependent $\mathrm{Na}^{+}$channels. Contrary to this lamotrigine acts by prolonging inactivation of voltage- 
sensitive $\mathrm{Na}^{+}$channels. Selectivity differences for the $\alpha$ subunits of $\mathrm{Na}^{+}$channels might be responsible for the two different mechanisms.

Lamotrigine (LTG), a new antiepileptic drug blocks voltage-dependent sodium channel and reduces excitatory neurotransmitter release, principally that of glutamate leaving normal glutamate release unaffected.

The mechanism by which seizure can develop in experimental animal include - the one in which the agents antagonize the GABA. So, those agents, which have GABA mimetic action or agents, which potentiate the action of GABA are supposed to have the protective effect or anti-eplileptic action.

The electric convulsiometer can also produce generalized tonic-clonic seizure in human and animals in easy manner. Many drugs have been tested which have protective effect against G.T.C.S. induced by electric convulsiometer.

The anticonvulsant activity of lamotrigine has been extensively studied and its role is established. Lamotrigine have shown recently to be useful in various epileptic seizure viz. G.T.C.S., status epilepticus, infantile spasm and myoclonic jerk. Since antiepileptic drugs are used for longer duration, so less toxic drugs should be chosen. So, in the present study the Lamotrigine has been chosen to compare the profiles of anticonvulsant action. It is also tried to compare the effectiveness, toxicity and lethal dose of the drug used in the study keeping the phenytoin as a standard drug.

\section{METHODS}

The present study has been carried out in the Department of Pharmacology, Darbhanga Medical College, Laheriasarai. Material used was Convulsiometer (Electrically operated), Tuberculin syringe and Albino mice. Drugs used were Dilantin Sodium (Phenytoin sodium) and Lamotrigine.

Induction of seizure with the help of electroconvulsiometer in albino mice was done followed by the observation of the anti-convulsant activity of lamotrigine in comparison with phenytoin sodium was made. Side effects or toxicity of the drugs used (Acute neurotoxicity) was observed.

The swinyard and co-workers method (1952 and 1965) was followed. The experimental animal (albino mice) was obtained from the animal house of Darbhanga Medical College.

\section{Maximal electroshock method}

The electro-shock convulsion was produced in the albino rates by the alternating current flow from electrical convulsiometer with the help of electrodes applied over the cornea. Every rat was screened for this test.
First of all, albino mice were selected with their average body weight ranging from $60 \mathrm{gm}$ to $100 \mathrm{gm}$. They were given free supply of foods and water for seven days rest period. Then they were divided into different groups randomly. Each group consisted of 6 mice. They were then numbered serially.

Production of maximal electroshock was produced by convulsiometer. The instrument provides alternating current of $50 \mathrm{~Hz}$ frequency. The time period is also electrically operated at 0.1 second internal from 0.1 to 1 second and the stimulus current of $0.2 \mathrm{~mA}$ to $500 \mathrm{~mA}$. The stimulus current of $150 \mathrm{~mA}$ to $220 \mathrm{~mA}$ of $50 \mathrm{~Hz}$ frequency is applied for 0.4 second with the help of electrodes applied over the right cornea. After applying the stimulus for convulsion, the mice passes tonic-clonic stage of convulsion. So, only those showing tonic convulsion one selected for the application to drugs. Now the control experiment is performed. In the experiment, keeping the time period constant at about 0.4 second, the current intensity of $150 \mathrm{~mA}$ onwards was applied. The intensity of current was increased from $150 \mathrm{~mA}$ in a serial increasing order. Now the point noted at which tonic convulsion was observed in all the animals in a single batch. So in this way, $210 \mathrm{~mA}$ current for 0.4 second was found to be suitable. At this point all control animals showed the tonic convulsion. The animals were given the drugs to be tested and in the absence of tonic convulsion it was considered that the drug had protective effect against the electro convulsion. So the positive or negative effects was thus recorded. The effect of different doses of the drugs at different levels were thus calculated. The data obtained was used for the calculation and tables are the inferences are thus drawn from that on statistical basis.

A comparative analysis, as regards the relative toxicity of a drug in the various tests as compared to standard anticonvulsant drug (dilantin sodium,) taking the toxicity of the later as unity, was determined. The toxicity of the standard anticonvulsant drug and the other drug were noted. The results analysed in terms of histogram. The variation in the TD 50 dose levels of the standard anticonvulsant drug was thus calculated.

Dilantin sodium was administered orally in 5\% gum acacia solution in distilled water through stomach canula fitted with a tuberculin syringe. Lamotrigine was also administered in 5\% gum acacia solution through stomach canula. In every set of experiment a controlled experiment with one group of six animals was performed and a comparative value after application of the same amount of the convulsive dose was obtained under identical condition.

The peak period of the drug action was determined previously by giving the requisite dose of the anticonvulsant drug. For the determination of the peak period MES test was employed due to its simplicity, ease and speed with which it could be performed. 
In each series of experiments the animals were observed for a period of one hour after the application of convulsive dose. The percentage of protection offered by the drug, the time interval after the application of the convulsive dose and the elicited positive tonic extensor response and lastly and mortality were noted. The tested animals were kept under observation for a further time of 24 hours in the laboratory and any further mortality were noted. The results thus obtained were tabulated in various tables.

To determine above mentioned factors standard laboratory procedures have been adopted to study the anticonvulsant effects of the drugs.

\section{RESULTS}

In this experiment, the positive response was taken as the extensor component of the hind leg in tonic phase of the seizure. Increase in current intensity (m.Amp) increases the number of animals showing positive response. The minimum current intensity for 0.4 second time period to produce $100 \%$ positive response was $210 \mathrm{~mA}$. No mortality was seen within one hour. Our study indicates that, $210 \mathrm{~mA}$ current for 0.4 second time period can produce the positive response in $100 \%$ of animals without any mortality.

A group of ten animals were taken and they were given metrazol in the dose of $8 \mathrm{mg} / 100 \mathrm{gm}$ of body weight. The animals were observed for a period of one hour and also within 48 hours after the administration of the drug. 100\% of the animals showed a characteristic clonic type of convulsion and $80 \%$ of the animals showed tonic type. Mortality rate was $20 \%$. Convulsion lasting less than 5 seconds were discarded. Positive response was taken as the animals showing tonic extensor component of the hind leg.
The drug dilantin sodium was introduced orally with the tuberculin syringe fitted with stomach canula. Two hours after the administration of the drug electro-shock of 210 $\mathrm{mA}$ for 0.4 second was applied and the positive response were noted. The positive response was shown by the abolition of the tonic extensor component of the hind leg during the tonic phase of convulsion. The mice were observed for one hour. This study indicates that 0.8 to 1.1 $\mathrm{mg} / 100 \mathrm{gm}$ of body weight of dilantin sodium provided $50 \%$ protection. (Mean value: $1 \mathrm{mg} / 100 \mathrm{gm}$ of body weight $\mathrm{SD} \pm 0.1, \mathrm{SEM} \pm 0.05)$.

\section{Peak period determination of dilantin sodium by MES Test}

The drug (Dilantin sodium) was administered orally through stomach canula. After the administration of the drug $(1.5 \mathrm{mg} / 100 \mathrm{gm}$ body weight) Dilantin sodium, the maximum protection period was between two to three hours, though the action was seen from $1 / 2$ hour to 5 hours. So, the maximum anticonvulsant action of phenytoin sodium was 2 - 3 hours.

\section{Effect of different doses of Dilantin Sodium}

All the animals of the batches were given different doses of dilantin sodium with the help of tuberculin syringe fitted with stomach canula. The doses given were ranging from $0.4 \mathrm{mg} / 100 \mathrm{ml}$ of body weight of $1.5 \mathrm{mg} / 100 \mathrm{mg}$ of body weight. Two hours after that, the animals showed the protective effect of the drug against electro-convulsion. The percentage of protection was increasing as the dose was increased. No animal was protected at $0.4 \mathrm{mg} / 100 \mathrm{gm}$ weight but $83.3 \%$ of the animals were protected at $1.5 \mathrm{mg} / 100 \mathrm{gm}$ of body weight. No mortality was observed upto $1.2 \mathrm{mg} / 100 \mathrm{gm}$ of body weight but at the dose of $1.5 \mathrm{mg} / 100 \mathrm{gm}$, one animal was killed. (P Value 0.00).

Table 1: Exhibiting the range of TD 50 of Dilantin sodium in acute neuro-toxicity test.

\begin{tabular}{|c|c|c|c|c|c|c|c|c|c|}
\hline \multirow{2}{*}{$\begin{array}{l}\text { Batch } \\
\text { No. of } \\
\text { animal }\end{array}$} & \multirow{2}{*}{$\begin{array}{l}\text { Dose of drug in } \\
\text { mg/100 gm of } \\
\text { body weight }\end{array}$} & \multicolumn{4}{|c|}{ Effect on animals } & \multirow{2}{*}{$\begin{array}{l}\text { Positive } \\
\text { response } \\
+ \text { ve }\end{array}$} & \multirow{2}{*}{$\begin{array}{l}\text { No. of animal } \\
\text { showing negative } \\
\text { response }\end{array}$} & \multirow{2}{*}{$\begin{array}{l}\% \text { of +ve } \\
\text { response }\end{array}$} & \multirow[b]{2}{*}{ Death } \\
\hline & & NT-P & NT-R & NT-G & NT-M & & & & \\
\hline 1 & 1.0 & - & - & - & - & 0 & 6 & 0 & 0 \\
\hline 2 & 1.5 & + & - & + & - & 1 & 5 & 16.6 & 0 \\
\hline 3 & 2.0 & + & - & + & - & 2 & 4 & 33.3 & 0 \\
\hline 4 & 2.5 & + & + & + & - & 3 & 3 & 50 & 0 \\
\hline 5 & 3.0 & - & + & + & - & 3 & 3 & 50 & 1 \\
\hline 6 & 3.5 & + & + & + & + & 5 & 1 & 83.3 & 1 \\
\hline
\end{tabular}

(1) NT-R - Position sense test, (2) NT-R - Righting reflex test, (3) NT-G - Gait and stance test, (4) NT-M - Muscle tone test SEM - \pm 0.16

The drug (Dilatin sodium) was given to each batches of the albino mice. The dose was ranging from $1.0 \mathrm{mg}$ to $3.5 \mathrm{mg}$ per $100 \mathrm{gm}$ of body weight. Two hours after the administration of the drug, the experimental animals were examined or the acute neuro-toxicity test like Position and sense test, Gait and stance test, righting reflex test and muscle tone test.

The minimum dose of the drug showing $50 \%$ toxic effect were $2.5 \mathrm{mg}$ per $100 \mathrm{gm}$ of body weight. 
(Mean value $-2.5 \mathrm{mg} / 100 \mathrm{gm}$ of body weight, S.D. - \pm 0.05 , S.E.M. - 0.16).

The observed T.D. 50 doses of dilantin sodium was $2.5 \pm 0.05 \mathrm{mg} / 100 \mathrm{gm}$ of body weight.

Lamotrigine was administrated through tuberculin syringe fitted with stomach canula. The dose administered ranges from $1 \mathrm{mg}$ to $4.0 \mathrm{mg}$ per $100 \mathrm{gm}$ of body weight. Now two hours after the administration of drug the electroshock of $210 \mathrm{~mA}$ for 0.4 second is applied through corneal electrode. The positive response is noted. Positive response is shown by the absence of the tonic extensor component of the hind leg during the tonic phase of convulsion. Albino rats were taken into observation for one hour after the application of electroshock.
The experiment has shown that Lamotrigine can protect $50 \%$ of animals at the dose ranging from $3.0 \mathrm{mg}$ per $100 \mathrm{gm}$ of body weight to $3.5 \mathrm{mg}$ per $100 \mathrm{gm}$ of body weight. So, the ED 50 is $3.5 \pm 0.1 \mathrm{mg}$ per $100 \mathrm{gm}$ of body weight. The mean value of the drug is $3.5 \mathrm{mg} / 100 \mathrm{gm}$ of body weight. $(\mathrm{SD} \pm 0.1)$.

This drug was administered orally with the help of stomach canula. The dose was kept of $3 \mathrm{mg} / 100 \mathrm{gm}$ of body weight of mice. Now the electroshock was applied for 0.4 second period of $210 \mathrm{~mA}$ intensity. Mice were observed for the positive response. The positive response was considered when the tonic extensor response component of hind leg during the tonic phase of convulsion was abolished. The mice were observed for one hour after the electroshock application. Peak period was 3 hours. The protective effect was seen maximum at 3 hours after the administration, after that the effect starts declining.

Table 2: The range of TD 50 of Lamotrigine in the acute neurotoxicity test.

\begin{tabular}{|c|c|c|c|c|c|c|c|c|c|}
\hline \multirow{2}{*}{$\begin{array}{l}\text { Batch } \\
\text { No. of } \\
\text { animal }\end{array}$} & \multirow{2}{*}{$\begin{array}{l}\text { Dose of drug in } \\
\text { mg/100 gm of } \\
\text { body weight }\end{array}$} & \multicolumn{4}{|c|}{ Effect on animals } & \multirow{2}{*}{$\begin{array}{l}\text { Positive } \\
\text { response }\end{array}$} & \multirow{2}{*}{$\begin{array}{l}\text { No. of animal } \\
\text { showing negative } \\
\text { response }\end{array}$} & \multirow{2}{*}{$\begin{array}{l}\% \text { of } \\
\text { Positive } \\
\text { response }\end{array}$} & \multirow[b]{2}{*}{ Death } \\
\hline & & NT-P & NT-R & NT-G & NT-M & & & & \\
\hline 1 & 2.5 & - & - & + & - & 1 & 5 & 16.6 & 0 \\
\hline 2 & 3 & - & - & + & - & 1 & 5 & 16.6 & 0 \\
\hline 3 & 3.5 & + & - & + & - & 2 & 4 & 33.3 & 0 \\
\hline 4 & 4 & + & + & + & + & 3 & 3 & 50.0 & 0 \\
\hline 5 & 4.5 & + & + & + & + & 3 & 3 & 50.0 & 0 \\
\hline 6 & 5 & + & + & + & + & 4 & 2 & 66.6 & 1 \\
\hline
\end{tabular}

(1) NT-P - Position sense test, (2) NT-R - Righting reflex test, (3) NT-G - Gait and stance test, (4) NT-M - Muscle tone test TD $504.5 \pm 0.5 \mathrm{mg} / 100 \mathrm{gm}$ of body weight.

Table 3: Effect of different doses of phenytoin against metrazol induced convulsion.

\begin{tabular}{|c|c|c|c|c|c|c|}
\hline \multirow{2}{*}{$\begin{array}{l}\text { Batch No. of } \\
\text { animals }\end{array}$} & \multirow{2}{*}{$\begin{array}{l}\text { Dose in mg. per } \\
100 \text { gm of body } \\
\text { weight }\end{array}$} & \multicolumn{2}{|c|}{$\begin{array}{l}\text { Effect of drug on different batches of } \\
\text { animals }\end{array}$} & \multirow{2}{*}{$\begin{array}{l}\text { Type of } \\
\text { convulsion }\end{array}$} & \multirow{2}{*}{$\begin{array}{l}\text { Percentage of } \\
\text { protection }\end{array}$} & \multirow{2}{*}{ Death } \\
\hline & & $\begin{array}{l}\text { No. of protected } \\
\text { animals }\end{array}$ & $\begin{array}{l}\text { No. of unprotected } \\
\text { animals }\end{array}$ & & & \\
\hline 1. & 1.0 & 0 & 10 & CC and T.E. & 0 & 4 \\
\hline 2. & 1.5 & 0 & 10 & CC and T.E. & 0 & 4 \\
\hline 3. & 2.0 & 0 & 10 & CC and T.E. & 0 & 4 \\
\hline 4. & 2.5 & 0 & 10 & CC and T.E. & 0 & 3 \\
\hline 5. & 3.0 & 0 & 10 & CC and T.E. & 0 & 3 \\
\hline 6. & 3.5 & 0 & 10 & CC and T.E. & 0 & 3 \\
\hline
\end{tabular}

CC - Clonic type of convulsion T.E. - Tonic extensor type of convulsion.

Lamotrigine was given to the animals at the doses ranging from $2.5 \mathrm{mg}$ to $5 \mathrm{mg} / 100 \mathrm{gm}$ of body weight. After that the acute neurotoxicity was determined at each dose in different groups. The gait and stance test were positive in one animals at the doses of $2.5 \mathrm{mg} / 100 \mathrm{gm}$ of body weight. All the parameters of neurological test were found positive at the minimum doses of $4 \mathrm{mg}$ per $100 \mathrm{gm}$ of body weight in half of the animals. No death of animals was seen upto the doses of $4.5 \mathrm{mg} / 100 \mathrm{gm}$ of body weight, but one death was observed at the doses of $5 \mathrm{mg} / 100 \mathrm{gm}$ of body weight.
The range T.D. 50 dose of Lamotrigine has been found to be $4.5 \mathrm{mg} / 100 \mathrm{gm}$ of body weight. (S.D. $= \pm 0.05$; $\mathrm{SEM}=$ 0.16). So, the observation TD 50 dose of lamotrigine has been $4.5 \mathrm{mg} \pm 0.05 \mathrm{mg} / 100 \mathrm{gm}$ of body weight.

Metrazol (Pentylenetetrazol) was given in the dose of 80$\mathrm{mg} / \mathrm{Kg}$ body weight S.C. after $2 \frac{1}{2}$ hour after the administration of phenytoin. A convulsion lasting more than 5 second was taken as the positive convulsion. The 
animals were observed for one hour and after 24 hours after the administration of metrazol.

Phenytoin was administered in the dose levels varying from $1.0 \mathrm{mg} / 100 \mathrm{gm}$. Of body weight to $3.5 \mathrm{mg} / 100 \mathrm{gm}$. Of body weight with the help of stomach canula. After the administration of metrazol, mortality was recorded $40 \%$ at the dose levels varying from 1.0 to $2.0 \mathrm{mg} / 100 \mathrm{gm}$ of body weight and $30 \%$ at the dose levels varying from 2.5 to $3.5 \mathrm{mg} / 100 \mathrm{gm}$. Of body weight. Hence it was observed that phenytoin is ineffective to protect chemoshock convulsion even in higher doses but the mortality is slightly reduced in higher doses. The dose of phenytoin varied from 1.0 to $3.5 \mathrm{mg} / 100 \mathrm{gm}$ of body weight.

Metrazol (Pentylenetetrazol) was given in the dose of 80$\mathrm{mg} / \mathrm{Kg}$ body weight S.C. after 3 hour after the administration of lamotrigine. A convulsion lasting more than 5 second was taken as the positive convulsion. The animals were observed for one hour and after 24 hours after the administration of metrazol.

Lamotrigine was administered in the dose levels varying from $2.5 \mathrm{mg} / 100 \mathrm{gm}$ of body weight to $5 \mathrm{mg} / 100 \mathrm{gm}$ of body weight with the help of stomach canula. After the administration of metrazol, mortality was recorded $0 \%$ at the dose level $2.5 \mathrm{mg} / 100 \mathrm{gm}$. And $10 \%$ at dose level varying from 3 to $3.5 \mathrm{mg} / 100 \mathrm{gm}$. Of body weight and $30 \%$ at the dose levels varying from 4 to $5 \mathrm{mg} / 100 \mathrm{gm}$ of body weight. Hence it was observed that lamotrigine is ineffective to protect chemoshock convulsion even in higher doses, but the mortality is slightly higher in higher doses. The dose of lamotrigine varied from 2.5 to $5 \mathrm{mg} / 100 \mathrm{gm}$ of body weight.

Table 4: Effect of different doses of lamotrigine against metrazol induced convulsion.

\begin{tabular}{|c|c|c|c|c|c|c|}
\hline \multirow{2}{*}{$\begin{array}{l}\text { Batch No. } \\
\text { of animals }\end{array}$} & \multirow{2}{*}{$\begin{array}{l}\text { Dose in } \mathrm{mg} \text {. } \\
\text { per } 100 \mathrm{gm} \text { of } \\
\text { body weight }\end{array}$} & \multicolumn{2}{|c|}{$\begin{array}{l}\text { Effect of drug on different batches of } \\
\text { animals }\end{array}$} & \multirow{2}{*}{$\begin{array}{l}\text { Type of } \\
\text { convulsion }\end{array}$} & \multirow{2}{*}{$\begin{array}{l}\text { Percentage of } \\
\text { protection }\end{array}$} & \multirow{2}{*}{ Death } \\
\hline & & $\begin{array}{l}\text { No. of protected } \\
\text { animals }\end{array}$ & $\begin{array}{l}\text { No. of Unprotected } \\
\text { animals }\end{array}$ & & & \\
\hline 1. & 2.5 & 0 & 10 & CC and T.E. & 0 & 0 \\
\hline 2. & 3.0 & 0 & 10 & CC and T.E. & 0 & 1 \\
\hline 3. & 3.5 & 0 & 10 & CC and T.E. & 0 & 1 \\
\hline 4. & 4.0 & 0 & 10 & CC and T.E. & 0 & 3 \\
\hline 5. & 4.5 & 0 & 10 & $\mathrm{CC}$ and T.E. & 0 & 3 \\
\hline 6. & 5.0 & 0 & 10 & $\mathrm{CC}$ and T.E. & 0 & 3 \\
\hline
\end{tabular}

CC - Clonic type of convulsion T.E. - Tonic extensor type of convulsion.

Table 5: The pharmacokinetic data.

\begin{tabular}{|ll|lll|}
\hline Drug & $\begin{array}{l}\text { Peak serum levels } \\
\text { (Hrs) }\end{array}$ & Half life (Hrs) & $\begin{array}{l}\text { \% or protein } \\
\text { binding }\end{array}$ & $\begin{array}{l}\text { Therapeutic range } \\
\text { (mcg/ml) }\end{array}$ \\
\hline Phenytoin & $1-12$ & $9-10$ & $89-92$ & $10-20$ \\
\hline Carbamazapine & $6-12$ & $24-60$ & $70-80$ & $4-10$ \\
\hline Phenobarbitone & $1-6$ & $53-140$ & $46-48$ & $15-40$ \\
\hline Ethosuccimide & $1-2$ & $60-100$ & Negligible & $40-100$ \\
\hline Sodium Vaklporate & $5-4$ & $8-15$ & 90 & $50-100$ \\
\hline Diazepam & $1-2$ & $20-42$ & $94-98$ & $40-60$ \\
\hline Lamotrigine & $2-18$ & $15-30$ & 55 & $3-5$ \\
\hline
\end{tabular}

\section{DISCUSSION}

Epilepsy is not a single disease entity. This is a collection of disorders of brain functions in which the most common symptom is partial or generalized fit or convulsions. These fits come in various forms hence the use of the term "epilepsies". Epilepsies have been generally managed by Diphenyl hydantoins, Barbiturates, Oxazolidions, succinamides. Recently carbamazepine, sodium valporate Benzodiazepines, lamotrigine and leviracetam have been added to the limited arementarium of antiepileptic drugs.
The pharmacokinetic data as shown below relevant to their clinical use are as follows: ${ }^{5}$

Phenytoin is a different drug to be use correctly in practices. The plasma protein binding is too fluctuating in different individuals. It has narrow therapeutic ratio which makes individualization of doses very important. The bioavailability problem and drug interactions are very common, and it exhibits saturation kinetics within the therapeutic range of serum concentration. The bioavailability changes in excipient. 
A large number of drugs have been mentioned in modern therapy which control the convulsive disorders. Anticonvulsant drugs for the present discussion are the agents having potential value in the treatment of epilepsy.

Previous workers suggested that mostly the drugs responsible to control grandmal were also responsible to control electroshock seizures or vice versa and the drugs for petitmal control chemoshock convulsion. The extensor component of the hind leg in the tonic phase of the convulsion was obtained and peak hour of the drugs related to their anticonvulsant property was determined after the oral administration of drugs.

Albino rats weighing $60-100 \mathrm{gm}$. were selected for determining the anticonvulsant effects of the drugs by M.E.S. test and chemoshock test. ${ }^{6}$ For the production of chemoshock convulsion metrazol was given subcutaneously in the dose of $80 \mathrm{mg} / \mathrm{Kg}$ body weight. The dose of the drug required for abolition of the tonic extensor component of the hind leg in 50\% animals (ED 50) either by electroshock or by chemoshock was observed. Low weight group of the animals were taken to get the least erratic responses of the different doses of the drugs.

Minimum amount of current producing maximal electroshock seizure in all the animals of a batch or the next batch was determined i.e. $210 \mathrm{~mA}$ for 0.4 second.

In chemoshock test metrazol was used in doses of $80 \mathrm{mg} / \mathrm{Kg}$ of body weight and the time for the onset of convulsion after administration of metrazol subcutaneously was determined 7.10 minutes.

Swinyard also recommended the administration of metrazol 10 minutes earlier to the peak period of the anticonvulsants. ${ }^{6}$ The protection produced by varying doses of phenytoin against electroshock was highly significant ( $\mathrm{P}$ Value $<0.001)$ which was identical to the previous observations. ${ }^{7}$ Phenytoin was completely ineffective against metrazol induced convulsions which again simulated previous workers report. ${ }^{8}$ And the mortality was higher i.e. $10 \%$ at the dose levels of 3 and $3.5 \mathrm{mg} / 100 \mathrm{gm}$. of body weight.).

Acute neurotoxicity produced by phenytoin was nil at the dose levels of $1 \mathrm{mg} / 100 \mathrm{gm}$. of body weight and $50 \%$ at $2.5 \mathrm{mg} / 100 \mathrm{gm}$. of body weight, $83.3 \%$ at the dose levels of $3.5 \mathrm{mg} / 100 \mathrm{gm}$. of body weight. TD 50 range was 2.5 to $3.0 \mathrm{mg} / 100 \mathrm{gm}$. of body weight mean being $3.0 \pm 0.1 \mathrm{mg} / 100 \mathrm{gm}$. of body weight. Dose response was highly significant ( $\mathrm{P}$ Value $<0.001$ ) and protective index of phenytoin has been found to be 6.1 which was also identical to previous records. ${ }^{7}$

The investigator is of opinion that the lamotrigine shares the equivocal or less anticonvulsant effect than phenytoin meanwhile it also has lower neurotoxicity and more safety margin but has lesser coverage range on different types of epilepsies except GTCS. So, it will not be too wiseful to be used clinically as an anticonvulsant drug alone as first choice drug for all types of epilepsies, unless an elaborate screening of the drug is made by further experiment.

\section{CONCLUSION}

Thus, it can be concluded that the Lamotrigine can be used clinically as anticonvulsant in Grandmal type of epilepsy but not in Petitmal epilepsy, and has equivocal anticonvulsant effect but slightly less toxicity to phenytoin but further elaborate screening of the drug by various experiments is needed to come to a precise conclusion.

Funding: No funding sources

Conflict of interest: None declared

Ethical approval: The study was approved by the Institutional Ethics Committee

\section{REFERENCES}

1. Ng SK, Brust JC, Hauser WA, Sausser M. Illicit drugs use and the risk of new-onset seizures. Am J Epidemiol. 1990;132:47-57.

2. Rutecki PA. Noradrenergic modulation of epileptiform activity in the hioppocampus. Epilepsy Res. 1995;20:125-36.

3. Stables JP, Kupferberg HJ. Chapter 16 - The NIH Anticonvulsant Drug Development (ADD) Program: preclinical anticonvulsant screening project. In: Molecular and cellular targets for anti-epileptic drugs. Eds. Avanzini G, Regesta G, Tanganelli P, Avoli M, John Libbey, London; 1997:191-198.

4. White HS, Woodhead JH, Wilcox KS, Stables JP, Kupferberg HJ, Wolf HH. Discovery and preclinical development of antiepileptic drugs. In: Antiepileptic drugs.Fifth edition. Eds. Levy RH, Mattson RH, Meldrum BS, Perucca E, Lippincott Williams \& Wilkins, Philadelphia; 2002:36-48.

5. Richens A. A text book of epilepsy, ed. Lastlavd, J. and Richens. A Edinburgh, Churchill Livingstone; 1976.

6. Swinyard EA, Brown WC, Goodman LS. Comparative assay of antileptic drugs in mice and rats, J. Pharmacol. Exp. Ther. 1952;106:319-30.

7. Ramzan I, Levy G. Relationship between Concentration and Anticonvulsant Effect of Phenytoin against Electroshock-Induced Seizures in Rats: Comparison of Sampling Sites for Concentration Determinations. J of Pharmac Sci. 1989;78(6):448-51.

8. Satoskar RS, Bhandarkar SDF. Pharmacol. \& Pharmacotherapeutics, 98, 3rd Ed. Popular Prakashan, Bombay; 1973.

Cite this article as: Singh AK. A comparative study of anticonvulsant effect of phenytoin and lamotrigine in albino mice. Int $\mathrm{J}$ Basic Clin Pharmacol 2017;6:2625-30. 